\title{
Slowly Progressive Type 1 Diabetes Mellitus Associated with Vitiligo Vulgaris, Chronic Thyroiditis, and Pernicious Anemia
}

\author{
Chiori SuzuKI, Yuichi HIRAI, Ken TeruI, Akira KoHSAKA, \\ Tomoaki AKAGI* and Toshihiro SUDA**
}

\begin{abstract}
A 81-year-old woman was diagnosed as having diabetes mellitus (DM) at 58 years of age. She started insulin therapy the following year, but her blood sugar levels were poorly controlled. At the age of 75 , she tested positive for the anti-GAD antibody $(7.8 \mathrm{U} / \mathrm{ml})$ and was diagnosed as having slowly progressive type 1 DM (SPIDDM), as well as vitiligo vulgaris. At 78 years of age, chronic thyroiditis was diagnosed after positive tests for anti-thyroid peroxidase antibody and anti-thyroglobulin antibody. At the age of 81, general fatigue and jaundice appeared concomitantly with severe anemia, with $\mathrm{Hb}$ levels at $5.2 \mathrm{~g} / \mathrm{dl}$. Low serum vitamin $B_{12}$ levels and the finding of erythroblastic hyperplasia with megaloblasts in bone marrow led to the diagnosis of pernicious anemia. Anemia was alleviated by intramuscular injections of vitamin $B_{12}$. The patient developed chronic thyroiditis, vitiligo vulgaris, and pernicious anemia concomitantly with SPIDDM, and was diagnosed as having polyglandular autoimmune syndrome type III. Attention should be paid to these potentially associated autoimmune diseases in daily practice during the follow-up of SPIDDM patients.
\end{abstract}

(Internal Medicine 43: 1183-1185, 2004)

Key words: slowly progressive type 1 diabetes mellitus, polyglandular autoimmune syndrome, vitiligo vulgaris, chronic thyroiditis, pernicious anemia

\section{Introduction}

Slowly progressive type 1 (insulin-dependent) diabetes mellitus (SPIDDM) is a disease in which diabetes mellitus (DM), after an initial non-insulin-dependent stage, progresses to an insulin-dependent state as a result of a gradual decrease in insulin secretion and the presence of autoantibodies for pancreatic islet cells. SPIDDM is known to often accompany other autoimmune diseases (1). Here, we report a case in which vitiligo vulgaris, chronic thyroiditis, and pernicious anemia were observed during the follow-up to SPIDDM.

\section{Case Report}

A 81-year-old woman complainted of general fatigue and jaundice. In her family history, her older sister had DM (without vitiligo vulgaris, chronic thyroiditis, or pernicious anemia). At 58 years of age, the patient complained of thirst and polyuria, and was diagnosed as having DM. She started taking medicines and insulin therapy was initiated in the following year. At 75 years of age she was referred and admitted to our hospital to control her blood sugar levels. She tested positive for the anti-GAD antibody $(7.8 \mathrm{U} / \mathrm{ml})$ and SPIDDM was considered when the clinical course was taken into account. At the same time, vitiligo vulgaris was diagnosed. She was followed-up later at the outpatient clinic, but her blood sugar levels were poorly controlled. At 78 years of age, hypothyroidism was found and positive tests for antithyroid peroxidase antibodies and anti-thyroglobulin antibodies led to the diagnosis of chronic thyroiditis. She visited the outpatient clinic complaining of general fatigue and jaundice in November 2002 at the age of 81 years.

On physical examination her height was $142.0 \mathrm{~cm}$, body

\footnotetext{
From the Department of Endocrinology, *the Department of Rheumatology and Hematology, Aomori Prefectural Central Hospital, Aomori and **the Department of Internal Medicine 3, Hirosaki University School of Medicine, Hirosaki

Received for publication March 12, 2004; Accepted for publication August 10, 2004

Reprint requests should be addressed to Dr. Yuichi Hirai, the Department of Endocrinology, Aomori Prefectural Central Hospital, 2-1-1 Higashitsukurimichi, Aomori 030-8553
} 
SUZUKI et al

Table 1. Laboratory Data

\begin{tabular}{|c|c|c|c|c|c|}
\hline$[\mathrm{CBC}]$ & & \multicolumn{2}{|c|}{ [Blood chemistry] } & $\mathrm{Na}$ & $136 \mathrm{mEq} / \mathrm{l}$ \\
\hline WBC & $3,600 / \mu 1$ & $\mathrm{TP}$ & $6.1 \mathrm{~g} / \mathrm{dl}$ & $\mathrm{K}$ & $4.7 \mathrm{mEq} / \mathrm{l}$ \\
\hline $\mathrm{RBC}$ & $122 \times 10^{4} / \mu 1$ & Alb & $3.7 \mathrm{~g} / \mathrm{dl}$ & $\mathrm{Cl}$ & $99 \mathrm{mEq} / \mathrm{l}$ \\
\hline $\mathrm{Hb}$ & $5.2 \mathrm{~g} / \mathrm{dl}$ & T-Bil & $3.71 \mathrm{mg} / \mathrm{dl}$ & $\mathrm{Ca}$ & $8.2 \mathrm{mEq} / \mathrm{l}$ \\
\hline $\mathrm{Ht}$ & $15.0 \%$ & D-Bil & $0.16 \mathrm{mg} / \mathrm{dl}$ & $\mathrm{P}$ & $3.7 \mathrm{mEq} / \mathrm{l}$ \\
\hline Plt & $12 \times 10^{4} / \mu 1$ & ALP & $314 \mathrm{IU} / l$ & Vitamin $B_{12}$ & $8 \mathrm{pg} / \mathrm{ml}$ \\
\hline $\mathrm{MCV}$ & $122.9 \mu \mathrm{m}^{3}$ & AST & $31 \mathrm{IU} / l$ & Folic acid & $10.3 \mathrm{ng} / \mathrm{ml}$ \\
\hline $\mathrm{MCH}$ & 42.6 Pg & ALT & $13 \mathrm{IU} / l$ & $\mathrm{HbA1c}$ & $7.0 \%$ \\
\hline \multirow[t]{5}{*}{ MCHC } & $34.6 \%$ & $\gamma$-GTP & $8 \mathrm{IU} / l$ & $\mathrm{FT}_{3}$ & $1.91 \mathrm{pg} / \mathrm{ml}$ \\
\hline & & LDH & $1,540 \mathrm{IU} / l$ & $\mathrm{FT}_{4}$ & $0.78 \mathrm{ng} / \mathrm{dl}$ \\
\hline & & CRE & $0.86 \mathrm{mg} / \mathrm{dl}$ & TSH & $4.11 \mu \mathrm{U} / \mathrm{ml}$ \\
\hline & & BUN & $25.2 \mathrm{mg} / \mathrm{dl}$ & ACTH & $29 \mathrm{pg} / \mathrm{ml}$ \\
\hline & & UA & $6.9 \mathrm{mg} / \mathrm{dl}$ & Cortisol & $14.8 \mathrm{mcg} / \mathrm{dl}$ \\
\hline
\end{tabular}

Table 2. Changes in Titers of Autoantibodies and Insulin Secretion

\begin{tabular}{lccc}
\hline Autoantibody & 75 years old & 78 years old & 81 years old \\
$\mathrm{S}-\mathrm{CPR}(1.5-3.5 \mathrm{ng} / \mathrm{ml})$ & 0.4 & $<0.1$ & \\
$\mathrm{U}-\mathrm{CPR}(20-30 \mu \mathrm{g} / \mathrm{day})$ & $<1$ & 4 & \\
$\mathrm{GAD} \mathrm{Ab}(<1.5 \mathrm{U} / \mathrm{ml})$ & $7.8(+)$ & $118.5(+)$ & $34.7(+)$ \\
Gastric parietal cell Ab $(<10)$ & & & $20(+)$ \\
Intrinsic factor $\mathrm{Ab}$ & & 9 & $(+)$ \\
Insulin $\mathrm{Ab}(<12 \%)$ & $75.6(+)$ & $337(+)$ \\
$\mathrm{TPO} \mathrm{Ab}(<0.3 \mathrm{U} / \mathrm{ml})$ & & $7.3(+)$ & $3.4(+)$ \\
$\mathrm{Tg} \mathrm{Ab}(<0.3 \mathrm{U} / \mathrm{ml})$ & & & \\
\hline
\end{tabular}

weight, $43.0 \mathrm{~kg}$; BMI, $21.3 \mathrm{~kg} . \mathrm{m}^{2}$; blood pressure, 110/50 $\mathrm{mmHg}$; pulse rate, 75 beats/min and regular; palpebral conjunctiva, anemic; bulbar conjunctiva, remarkably icteric; cardiac sound, no murmur; pulmonary sound, normal vesicular sound and no rale; abdomen, no abnormal findings; and skin, white patches all over the body. Her blood cell count demonstrated pancytopenia with macrocytic anemia (Table 1). Her blood cell count two years previously at 79 years of age did not indicate pancytopenia (WBC $5,800 / \mu 1, \mathrm{RBC} 346 \times 10^{4} / \mu 1$, $\mathrm{Hb} 10.7 \mathrm{~g} / \mathrm{dl}$, Ht $31.4 \%$, Pl $28.1 \times 10^{4} / \mu \mathrm{l}$, MCV $90.6 \mu \mathrm{m}^{3}, \mathrm{MCH}$ $31.0 \mathrm{Pg}$, MCHC $34.2 \%$ ). Despite high total bilirubin levels, direct bilirubin levels were within the normal range, indicating abnormally high indirect bilirubin levels. LDH, serum creatinine, BUN, and uric acid levels were high. Serum $B_{12}$ was low $(8 \mathrm{pg} / \mathrm{ml})$. Taking the results together, pernicious or hemolytic anemia was suspected. On bone marrow biopsy, a remarkable proliferation of erythroblasts, the existence of megaloblasts, and high ratios of segmented granulocytes were found. These findings were consistent with those of pernicious anemia.

Immunological tests (Table 2), such as the direct Coombs' test were negative, the possibility of autoimmune hemolytic anemia was excluded. Anti-nuclear antibody and anti-gastric parietal cell antibody tests and intrinsic factor antibody were positive. The titer of anti-GAD antibody fluctuated over time and was not associated with insulin secretion as calculated by C-peptide reactivity. Positive titers for anti-thyroid pero- xidase and thyroglobulin antibodies were found for the first time at 78 years of age, but neither the antibody titers nor the thyroid function changed dramatically in the three years since then . HLA typing revealed A33 (19), A24 (9), B44 (12), B54 (22), DR13 (6), and DR 4.

\section{Discussion}

Polyglandular autoimmune syndrome (PGAS) is characterized by the development of disorders in multiple endocrine and non-endocrine systems that are mediated by autoimmune mechanisms $(2,3)$. There are three categories of PGAS. Types I and II develop Addison's disease while type III does not. In addition to Addison's disease, type I is characterized by chronic mucocutaneous candidiasis and hypoparathyroidism, while type II is characterized by autoimmune thyroid disease and type 1 DM. Type III, which is characterized by autoimmune thyroid disease and the absence of Addison's disease, is accompanied by type $1 \mathrm{DM}$, pernicious anemia and vitiligo and/or alopecia (2). The present case with SPIDDM accompanied by vitiligo vulgaris, chronic thyroiditis, and pernicious anemia, and the absence of Addison's disease, which was considered to be consistent with PGAS type III. According to previous reports in these recent 8 years, and including our case, there have been four domestic cases of SPIDDM (one male and three females) in which positive tests for the anti-GAD antibodies were 
Table 3. Clinical Characteristics of the 4 Cases Reported in Japan

\begin{tabular}{|c|c|c|c|c|c|c|c|c|}
\hline \multirow[b]{2}{*}{ Age/sex } & \multicolumn{3}{|c|}{ Diabetes mellitus } & \multicolumn{3}{|c|}{ Concomitant disease } & \multirow[b]{2}{*}{ BMI } & \multirow[b]{2}{*}{ Reference } \\
\hline & Age of onset & $\begin{array}{c}\text { Age a } \\
\text { of } C\end{array}$ & $\begin{array}{l}\text { ration } \\
\text { lin }\end{array}$ & $\begin{array}{l}\text { Pernicious } \\
\text { anemia }\end{array}$ & $\begin{array}{l}\text { Chronic } \\
\text { thyroiditis }\end{array}$ & $\begin{array}{l}\text { Vitiligo } \\
\text { vulgaris }\end{array}$ & & \\
\hline $69 / \mathrm{F}$ & 40 & 65 & 68 & 68 & 68 & $(-)$ & 19.3 & 3 \\
\hline $83 / \mathrm{M}$ & 73 & 75 & 83 & 71 & 83 & 83 & 23.5 & 4 \\
\hline $72 / \mathrm{F}$ & 60 & 60 & 71 & 72 & $(-)$ & $(-)$ & 20.8 & 5 \\
\hline $81 / \mathrm{F}$ & 58 & 58 & 59 & 81 & 78 & 59 & 21.3 & Our case \\
\hline
\end{tabular}

*oral hypoglycemic agent.

accompanied by pernicious anemia (Table 3) (4-6). When the onset times of DM and anemia were compared, the pernicious anemia appeared late in life in all cases $(68,71,72$, and 81 years of age, respectively). In one case it developed one year before the diagnosis of DM (5), while it developed long after the diagnosis of DM in the other three cases $(12,23$, and 28 years afterwards, respectively). In three of the reported cases, ours included, DM with pernicious anemia was accompanied by chronic thyroiditis $(4,5)$, and each case was diagnosed long after the onset of DM (10, 20, and 28 years afterwards, respectively). Furthermore, including ours there have been two reported cases with concomitant development of vitiligo vulgaris (5) which appeared one year and 10 years, respectively, after the onset of DM. BMI in the four cases were $19.3,23.5,20.8$, and $21.3 \mathrm{~kg} / \mathrm{m}^{2}$, respectively, and none of the subjects was obese.

It is known that type 1 DM generally develops around 1113 years while SPIDDM appears at an older age and there is a female predominance. A high titer of anti-GAD antibodies is a common feature and this is often accompanied by autoimmune disease (1). The reason for this has yet to be elucidated, but GAD is expressed in susceptible tissues such as pancreatic B cells, gastric parietal cells, and thyroid follicular cells (7), and the possibility of provoked autoimmune reactions and the involvement of HLA-DR4 (also found in our case) has been suggested $(1,8,9)$.

It is predicted that late onset DM patients will be increasingly encountered in the future because of the expanding elderly population. On suspicion of SPIDDM, antibody levels should be determined in patients who develop DM in later life without having a family history of DM or obesity. Jaeger et al analyzed sera from 197 recent-onset type 1 diabetic patients at the time of diagnosis, 882 first-degree relatives. They recommended routine screening for concomitant autoimmune thyroid disease in the first-degree relatives of type 1 diabetic patients (10). However autoimmune thyroid dis- ease was not observed in the first-degree relatives in our case.

In cases with a positive anti-GAD test, the potential existence of other associated autoimmune diseases should be taken into account in daily practice. As both pernicious anemia and chronic thyroiditis tend to appear long after the onset of DM, particular attention must be paid to them.

\section{References}

1) Kobayashi T, Tamemoto $K$, Nakanishi $K$, et al. Immunogenetic and clinical characterization of slowly progressive IDDM. Diabetes Care 16: 780-788, 1993.

2) Neufeld M, Maclaren N, Blizzard R. Autoimmune polyglandular syndromes. Pediatr Ann 9: 154-162, 1980.

3) Meyerson J, Lechuga-Gomez EE, Bigazzi PE, Walfish PG. Polyglandular autoimmune syndrome: current concepts. CMAJ 138: 605-612, 1988.

4) Takebe N, Fujimaru K, Matsubara K, et al. GAD antibody-positive slowly progressive insulin-dependent diabetes mellitus associated with pernicious anemia: A case report. J Jpn Diab Soc 43: 367-371, 2000.

5) Morita H, Yamada K, Wada Y, et al. Slowly progressive diabetes mellitus type 1 with pernicious anemia and chronic thyroiditis in an elderly patient. J Jpn Diab Soc 44: 831-836, 2001.

6) Kamoi K, Soga N, Takagi M. ICA-positive diabetes mellitus with pernicious anemia in an elderly woman. J Jpn Diab Soc 39: 47-51, 1996.

7) Erdo SL, Wolff JR. Gamma-aminobutyric acid outside the mammalian brain. J Neurochem 54: 363-372, 1990.

8) Horton V, Stratton I, Bottazzo GF, et al. Genetic heterogeneity of autoimmune diabetes: age of presentation in adults is influenced by HLA DRB1 and DQB1 genotypes (UKPDS 43). UK Prospective Diabetes Study (UKPDS) Group. Diabetologia 42: 608-616, 1999.

9) Kobayashi T, Sugimoto T, Itoh T, et al. The prevalence of islet cell antibodies in Japanese insulin-dependent and non-insulin-dependent diabetic patients studied by indirect immunofluorescence and by a new method. Diabetes 35: 335-340, 1986.

10) Jaeger C, Hatziagelaki E, Petzoldt R, Bretzel RG. Comparative analysis of organ-specific autoantibodies and celiac disease-associated antibodies in type 1 diabetic patients, their first-degree relatives, and healthy control subjects. Diabetes Care 24: 27-32, 2001. 